IZA DP No. 10153

How Do Labor Representatives Affect Incentive Orientation of Executive Compensation?

Katharina Dyballa

Kornelius Kraft

August 2016

Forschungsinstitut zur Zukunft der Arbeit Institute for the Study of Labor 


\title{
How Do Labor Representatives Affect Incentive Orientation of Executive Compensation?
}

\author{
Katharina Dyballa \\ TU Dortmund \\ Kornelius Kraft \\ TU Dortmund, ZEW and IZA
}

Discussion Paper No. 10153
August 2016

IZA
P.O. Box 7240
53072 Bonn
Germany

Phone: +49-228-3894-0

Fax: +49-228-3894-180

E-mail: iza@iza.org

Any opinions expressed here are those of the author(s) and not those of IZA. Research published in this series may include views on policy, but the institute itself takes no institutional policy positions. The IZA research network is committed to the IZA Guiding Principles of Research Integrity.

The Institute for the Study of Labor (IZA) in Bonn is a local and virtual international research center and a place of communication between science, politics and business. IZA is an independent nonprofit organization supported by Deutsche Post Foundation. The center is associated with the University of Bonn and offers a stimulating research environment through its international network, workshops and conferences, data service, project support, research visits and doctoral program. IZA engages in (i) original and internationally competitive research in all fields of labor economics, (ii) development of policy concepts, and (iii) dissemination of research results and concepts to the interested public.

IZA Discussion Papers often represent preliminary work and are circulated to encourage discussion. Citation of such a paper should account for its provisional character. A revised version may be available directly from the author. 
IZA Discussion Paper No. 10153

August 2016

\section{ABSTRACT \\ How Do Labor Representatives Affect Incentive Orientation of Executive Compensation?*}

Contrary to previous literature we hypothesize that labor's interest may well - like that of shareholders - aim at securing the long-run survival of the firm. Consequently, employee representatives on the supervisory board could well have an interest in increasing incentivebased compensation to avoid management's excessive risk taking and short-run oriented decisions. We compile unique panel data on executive compensation over the periods 2006 to 2011 for 405 listed companies and use a Hausman-Taylor approach to estimate the effect of codetermination on the compensation design. Finally, codetermination has a significantly positive effect on performance-based components of compensation, which supports our hypothesis.

JEL Classification: J52, L20, G32, M12, C33

Keywords: executive compensation, board representation, principal-agent theory, corporate finance, Hausman-Taylor

Corresponding author:

Kornelius Kraft

Faculty of Business, Economics and Social Science

TU Dortmund

Vogelpothsweg 87

D-44227 Dortmund

Germany

E-mail: kornelius.kraft@tu-dortmund.de

\footnotetext{
* We are very grateful to the Kienbaum Consulting AG for the kind provision of extensive data on management compensation. We should also like to thank the Hans Böckler Stiftung for kindly providing information on coverage of German firms by codetermination. We also thank the Deutsche Forschungsgemeinschaft for financial support via SFB 823 "Statistical modelling of nonlinear dynamic processes".
} 


\section{Introduction}

In all developed countries labor markets are shaped by interventions through laws and institutions (Botero et al. 2004). State regulations encompass labor law, collective bargaining laws as well as institutions like unions, and social security provisions like employment protection or unemployment benefits. Perotti and Thadden (2006) state that labor market institutions are the result of political decisions and these decisions in turn are determined by the interests of the voters. Once introduced, politically induced changes in corporate governance institutions affect rent creation positively or negatively and furthermore determine distribution of rents.

German codetermination is in a way an extreme politically mandated intervention into corporate governance structure in that $50 \%$ of the seats on the supervisory boards (which among other tasks appoint and control the executives) go to representatives of labor ${ }^{1}$. This offers the unique opportunity to examine how such a strong power of labor affects efficiency of the firms. It may be argued that labor has an interest in deviation from longterm profit maximizing behavior ${ }^{2}$ If this were true, labor might argue for an executive compensation package with large fixed components but not much incentive orientation by means of variable, profit related pay On the basis of a largely profit independent remuneration management might be less strongly induced to pursue cost minimization. The codetermined supervisory boards determine compensation of executives and also the composition in terms of fixed and variable parts. We investigate whether codetermined supervisory boards really reduce incentive orientation of executive compensation as e.g. Gorton and Schmid (2004) have stated.

Our study is not only relevant for Germany. On the one hand it is a test on what happens if labor has $50 \%$ of the votes in the determination process of executive compensation and this is probably a question of general interest. On the other hand Germany is the largest economy in which employees have the legal right to such participation, but it is not the only one. Denmark, Sweden, Austria, the Netherlands and Luxembourg have similar

\footnotetext{
1 "An interesting political construction is the attempt to let labor directly influence corporate decision making. The most pronounced incarnation of this idea is compulsory labor codetermination as practiced in large German firms" (Perotti and Thadden 2006, 160).

${ }^{2}$ Codetermination might well affect employment decisions to a larger degree than remuneration (Kraft 2001).
} 
codetermination laws (but with lower percentage of total votes). Italy and the remaining West European countries (with the exception of the UK) implement work councils at the very least. French companies send non-voting employees to the board (Smith 1991). Addison $(2009,1)$ regards the German system of employee representation as a template for policy formation in the European Union.

The classical theoretical approach explaining performance-based management compensation is the principal agent model that discusses the divergence in interests of a firm's owner and manager. Shareholders are interested in maximizing long-run firm value while managers like to maximize their utility, which in turn is determined by compensation, large expense accounts, prestige and power. Many of the determinants of managers' utility are size-related and therefore incentives exist to overemphasize growth. Performance-based executive compensation contracts are used in such situations as instruments to balance the long-term interests between shareholders and managers.

The analysis may however be incomplete if the influence of workers as important stakeholders is neglected. As stated above regulation offers labor possibilities to influence decision making and the German system of codetermination is an exposed example for this.

Incentive-orientated contracts intend to motivate managers more towards profit maximization and this in turn could be a matter of cost minimization. In the context of codetermination one hypothesis is that employees want to avoid cost minimization strategies, which among other items include wage reductions (or low increases) and fast employment adjustments if this is necessary in times of crisis. Then codetermination could exert a negative impact on the incentive orientation of executive compensation.

In this study we discuss and test the opposite hypothesis namely that the frequently assumed difference in the objective function of shareholders and employees may not exist. On the contrary, employees could have an interest in setting incentives for the managers, such that the executives make decisions to guarantee the survival of a firm in the long term. For example, it is not in the interest of the employees that the topmanagement pursues overly risky expansion projects, implying a considerable overlap between the interests of employees and shareholders. The codetermination rights of workers in particular are of relevance, as it is at least questionable whether control exerted by other forces really leads to optimal management compensation schemes ${ }^{3}$.

\footnotetext{
${ }^{3}$ Cf. for surveys Adams et al (2010), Murphy (2013) and for a quite critical view Bebchek and Freid (2004).
} 
Only a limited number of empirical studies exist that consider the effect of German codetermination on management compensation, especially on the performance orientation of executive compensation ${ }^{4}$. Gorton and Schmid (2004) use a sample of 250 listed companies in Germany that traded at the end of the year 1993 and are either quasiparity codetermined or are subject to the weaker one-third codetermination. Due to limited publication obligations in Germany at this time the only available information on compensation is the ratio of total management board compensation to the number of members. To model pay-performance sensitivity the authors interact a performance indicator with a dummy variable indicating whether the company is equally represented. By means of the nearest-neighbor method, they found out that the link between executive compensation and firm performance at equal-representation companies is significantly negative. Thus the authors conclude that management board compensation provides incentives that are not conducive to pursuing shareholders' interests.

Edwards et al (2009) use a sample of 1,145 observations on 271 listed companies in Germany for the years 1989-1993. The authors investigate the effect of codetermination on pay for performance using a fixed-effect approach. Similar to Gorton and Schmid (2004) they use an interaction term to model pay-performance sensitivity. However, their results differ from Gorton and Schmid's (2004) as the coefficient of this interaction term is positive in several specifications, although never statistically significant due to problems of collinearity ${ }^{5}$.

In Germany there have been some recent changes in law concerning publication obligations of executive compensation. The so-called VorstOG ${ }^{6}$ which became effective in 2006 for the first time requires the disclosure of detailed German data on different components of compensation. Henceforth, German listed corporations are obliged to publish the amount and composition of individual board members' compensation. The compensation is differentiated into fixed, short-term performance-based and long-run performance-based parts. This new opportunity of access to German data on executive compensation enables empirical research with a detailed look on the effect of codetermination on components of compensation in terms of fixed versus variable shares.

\footnotetext{
${ }^{4}$ For a recent general study on executive compensation in Germany have a look at Fabbri and Marin (2015).

${ }^{5}$ Edwards et al (2009) use return on assets as performance indicator whereas Gorton and Schmid (2004) use the ratio of market to book value of equity. Edwards et al (2009) point out that accounting profitability was explicitly specified as performance indicators by the Aktiengesetz, such that their performance indicator is more suitable.

${ }^{6}$ Gesetz über die Offenlegung der Vorstandsvergütung
} 
Although from an international perspective employee representation by membership on supervisory boards is rather special, there are studies from other countries that are related to our research question. Outside Germany workers' interests are mostly represented by unions and it is of interest what effect unions have on management compensation.

Some studies have estimated the direct effect of union presence on the level of executive compensation. All studies detected a significant impact of unionization on executive compensation but with quite heterogeneous directions ${ }^{7}$. Nonetheless this literature underlines the importance of our research question, namely to what extent labor as a stake- but not shareholder is able to influence managerial compensation.

Below, Section 2 presents the economic and institutional framework of the German board model and the impact of codetermination. Section 3 then provides an overview of the data, the econometric framework and the empirical results. Finally, Section 4 concludes.

\section{The German Board Model and the Impact of Codetermination}

In the past the number of stock companies was rather limited. Since 1997 the number of stock and joint- stock companies increased rapidly ${ }^{8}$. In general, the shareholders do not manage the firm themselves. As a result, the classical problem of separation between ownership and control (Berle and Means 1932) exists. This separation implies the risk of opportunistic behavior, i.e. the management's ability to manage the company to its own advantage at the shareholders' expense.

The standard framework describing this divergence of interests is the principle agent theory where the shareholder (principle) engages the manager (agent) to perform on his or her behalf (Jensen and Meckling 1976). In the textbook model the shareholders provide capital, bear the risk of investment and receive the profits as a compensation for risk bearing. The managers execute the operating business and are closely and effectively monitored by the shareholders.

\footnotetext{
${ }^{7}$ Gomez and Tzioumis (2013) present a good overview of existing literature: using U.S. data DiNardo et al (1997) find that greater levels of unionization were negatively and significantly associated with CEO cash pay. Banning and Chiles (2007) report that in the U.S. union presence, as well as the unionization rate at firm level, are negatively related to both the level of total CEO compensation and the proportion of CEO compensation that is contingent on firm performance. Based on Canadian data Singh and Agarwal (2002) show that union presence is associated with higher CEO cash pay, but not associated with other compensation components (e.g. stock options) and total compensation. Gomez and Tzioumis (2013) find evidence that union presence is associated with lower levels of total executive compensation in the U.S., especially lower stock option awards. The elasticity of cash pay to financial performance is similar across unionized and not unionized firms. (US)

${ }^{8}$ From 4,548 stock and joint-stock companies in 1997 to 14,184 stock and joint-stock companies in 2008 (Statista)
} 
Clearly, this model ignores information problems and hardly describes reality in modern stock companies. Managers have their own interests and are only imperfectly monitored. As a consequence managers might pursue their own utility maximization leading to (overly) risky projects, short-run profit maximization and expansion by mergers and acquisitions, which are not in the interest of shareowners. The more diversified capital ownership is, the more difficult effective execution of control is and the more relevant agency costs become.

These so-called corporate governance problems have been known about for some time and instruments are applied to limit managers' activities that do not maximize the discounted present value of the firm. Such instruments include, for example, institutions that help to supervise top managers and incentive-compatible contracts. The working and effectiveness of such instruments is the topic of our contribution.

The internal corporate governance structure for German stock companies differs from the Anglo-Saxon one ${ }^{9}$. The American Board of Directors, for example, manages and supervises simultaneously whereas the German two-tier board system separates between a managing and a supervising institution, respectively between an executive and a supervisory board.

Besides operative decision-making the executive board has to call the Annual General Meeting and implements its resolutions. Furthermore it has to report to the supervisory board. The supervisory board advises and supervises the executive board. In principle the supervisory board is expected to act in the best interest of the company. Given that the members of the supervisory boards are elected by the shareholders (and their representatives) control of the executive board should be in compliance with the shareholders' interests. Thus, this institution has to ensure that the executive board's decisions are made in accordance with the shareholders' interests. Supervisory board members also decide on the adoption of the financial statements and approval of the consolidated financial statements. Another major decision area of the supervisory board is the selection, appointment, contract-renewal and dismissal of the executive board members. A subcommittee of the supervisory board, the personnel committee, decides on total compensation of top management and the composition of compensation in terms of fixed versus short- and long-run variable parts ${ }^{10}$. Hence the supervisory board on the one

\footnotetext{
${ }^{9}$ See for a survey on the role of boards of directors in the U.S. Adams, Hermalin and Weisbach (2010).

${ }^{10}$ In the American corporate governance system the design and level of management compensation is delegated to compensation committees. Within these committees mostly outside members of the board of
} 
hand exerts control over managers and on the other hand is responsible for the implementation of an effective and incentive-compatible compensation scheme.

Given that shareholders and managers are interested in monetary values, incentive-based management compensation schemes could align shareholders’ and managers’ interests ${ }^{11}$. Therefore, the management's compensation design should be divided into a fixed and a variable share. The variable share, e.g. bonus payment, profit sharing bonuses or stock options, should depend on key values indicating a profit- and value-increasing firm policy. Thus by increasing the variable part of management's compensation the intention is to reduce or even to inhibit the incentives of pursuing opportunistic behavior.

\section{Inefficiency of the supervisory board}

The institutional differentiation into a management and a supervisory board in principle improves the task of controlling the top management. Obviously, the effectiveness of minimizing agency costs depends on the efficiency of the supervisory board. If the shareholders' interests are not represented adequately by supervisory board members, the risk of opportunistic behavior by management remains.

One major problem of this system is that supervisory boards are not dominated by the shareholders themselves, as one might assume in the first place. In fact, in the majority of supervisory boards not a single member is a capital owner ${ }^{12}$. Here we find the very specific and at the same time complicated situation where the principals appoint agents who control other agents. As the usual principal-agent problem is intensified, it would not be surprising if such a system did not work efficiently ${ }^{13}$.

directors (directors who are neither current nor former employees) make decisions on executive compensation (Murphy (1999)).

${ }^{11}$ De Cesari and Ozkan (2015) is a recent empirical study on the effect of executive incentives on payout policy in Europe. The authors show that executive incentives in form of stock-based pay- performance sensitivity and stock ownership help to align the interest of the shareholders and executives by significantly increasing the level of total payout. By the use of German data Jirjahn and Kraft (2010) show that managerial incentive payments induce a more performance oriented wage structure for blue collar workers resulting in an increased wage inequality between skilled and unskilled workers.

Leonard (1990) investigates U. S. data and finds out that long-term incentive remuneration plans for executives lead to a greater increase in firm performance.

12 Lattemann (2010) refers to this phenomenon in the German governance system and Gralla and Kraft (2011) present some empirical evidence. Kahn et al. (2014) suggest distinguishing between share ownership by executive directors having responsibility for the day-to-day business and share ownership by nonexecutive directors (one-tier system). The executive's decisions might be more closely tied to firm performance if they hold shares. There is evidence that the share ownership of independent non-executive board members (which could be seen as a counterpart to the German supervisory board) is relatively small at $1.9 \%$ for an Australian dataset (Kahn et al. (2014)) and between 1.92\% and 3.09\% for an American dataset (Mura (2007)).

${ }^{13}$ Canyon and He (2004) show that the presence of shareholders on the compensation committee of U.S. entrepreneurial firms lowers CEO compensation and increases CEO equity incentives. These results 
Murphy (2013, p. 322) raises general concerns with respect to the role of outside directors in the U.S. context: "However, these outside board members - who pay executives with shareholder money and not their own - are in no sense perfect agents for the shareholders who elected them.” He points out that outside directors often hold only minor quantities of the shares and are reluctant to punish badly performing CEOs because they do not benefit much from these changes yet bear all of the non-monetary costs.

Furthermore, Lattemann (2010) mentions that former executive board members (after retirement) relatively often become members of supervisory boards of the same company. Oehmichen et al. (2014) proved this empirically by showing that in $25 \%$ of all observed firm-years the former executive is currently serving as a supervisory board member within the same company. In cases like this it is difficult to regard former CEOs as true outsiders and efficient supervisors. They are familiar with most of the current members of the management board and also with most other managers. Where top management compensation is to be determined, they might support the view of the executives. Furthermore in cases where problems arise due to their own wrong decisions in the past, they will hardly act as neutral supervisors. This could lead to a kind of intertemporal selfmonitoring. It might violate the separation of supervision and management, at least for past decisions. Consequently Oehmichen et al. (2014) showed that these former executives have a significant negative impact on firm performance.

In Germany the legal number of supervisory board mandates is limited to a maximum of ten seats and some persons actually hold that many supervisory board seats. In such cases the supervisory board members simply cannot efficiently execute their control duties due to individual time constrains (Aurich (2006)). Existing literature discusses this argument as the "busyness hypothesis" saying that directors with multiple appointments are overcommitted (Ferris et al. (2003), Fich and Shivdasani (2006)) $)^{14}$.

Inefficiency could also occur due to the fact of interlocked board members, i.e. members of the supervisory boards are frequently executives from business partners, including banks ${ }^{15}$. There are usually loyal relations between the members of the management board and those members of the supervisory boards who are themselves top managers

support the hypothesis that due to intensified agency problems the degree of incentive-orientated compensation schemes falls.

14 There is much debate as to what extent the "busyness hypothesis" is true. Some studies argue that a large number of board mandates is a sign of quality. For further discussion see Adams et al. (2010) or Andres et al. (2013).

15 There is debate surrounding the efficiency effects of bank representation on German boards. See among others Gorton and Schmid (2000) and Edwards and Fischer (1994). 
elsewhere. Networking is likely to take place, which might on the one hand have its benefits for members of the network, but on the other hand effective control of the executives and efficient design of their contracts is questionable ${ }^{16}$. It is possible that reasonable decisions by the supervisory board which in principle would be valuable to the company, but affect the management negatively, would then be avoided to secure friendship and the personal network.

Bebchuk and Fried (2004) describe gains from the above-mentioned forces of collegiality, team spirit and respect for those leading the firm as spillover rents which come largely at the expense of shareholders ( $p$ 64). Thus, Adams et al. (2010) stress the importance of the independence of the board (discussing the U.S. experience) from the CEO to execute adequate control and collect information to decide on a possible contract renewal or replacement. As the authors emphasize, CEOs prefer less independent boards to be less closely monitored and to be able to maximize their own utility. ${ }^{17}$

Given these potential reasons for inefficiency, it is at least possible that the supervisory board members' motivation to implement efficient performance incentives is limited, which would be reflected in a relatively low share of incentive-based executive compensation. ${ }^{18}$

\footnotetext{
${ }^{16}$ Kramarz and Thesmar (2013) show that networking determines board composition in France, that networked CEOs have higher incomes and that networks within the board reduce its efficiency. Battistin, Graziano and Parigi (2012) investigate the role of local connections on turnover and performance of Italian banks. Connections reduce turnover, attenuate the relation between performance and turnover, and worsen the performance of mutual, cooperative and local banks.

${ }^{17}$ Whereas in America there is a huge amount of literature on the monitor quality of dependent board members and its effects on firm performance, there is only little empirical literature for Germany. Recently, Anders et al. (2013) used a sample of 133 German firms and found out that firms with intensely connected supervisory boards have lower firm performance and a higher level of executive compensation. American empirical evidence mostly detects a negative impact of interlocking directorates on (indirect) firm performance. Hallock (1997) examined the effect of reciprocally interlocked boards on executive compensation in the US. He states that $8 \%$ of CEOs are reciprocally interlocked with another CEO and shows that CEOs of interlocked firms earn significantly more. Newman and Mozes (1999) examine the efficiency of the compensation committee when insiders are members of the compensation committee. Insiders are either employees of the current firm or employees of other firms that are well connected with the current firm. With insiders on the board, executive compensation is more favorable for the executive, but at the expense of shareholders. In particular they show that pay performance sensitivity is less weighted on inferior performance when insiders serve on the compensation committee. Chhaochharia and Grinstein (2009) show that CEO pay fell by 17\% in firms which introduced more independent boards in comparison to firms which already had implemented such independent boards. Hwang and Kim (2009) find that while $87 \%$ of boards are conventionally independent only $62 \%$ are conventionally and socially independent (without social ties). They detect that firms in the latter group pay a lower level of compensation and exhibit stronger pay-performance sensitivity. Faleye (2011) proved empirically that CEOs are paid more and their compensation is less sensitive to firm performance when other CEOs serve on their boards.

${ }^{18}$ Sun and Cahan (2009) compute a composite measure of compensation committee quality based on six different committee quality characteristics (1. CEO appointed directors, 2. senior directors, 3. CEO directors, 4. director shareholdings, 5. additional directorships and 6. committee size). By using a sample
} 
The impact of codetermination

Due to the rapid growth of stock companies the classical shareholder value approach has gained importance in recent decades. Basically, this approach stipulates maximization of the shareholders' equity. There are two interest groups: shareholders and managers. The principals are expected to efficiently determine management compensation in general and its components in particular.

Within this context the German codetermination law ${ }^{19}$ introduces a third interest group, namely the employees. In companies with more than 2000 employees $50 \%$ of the seats of the supervisory board are legally filled by employee representatives ${ }^{20}$. This form of codetermination has been called "quasi-parity”, as the head of the supervisory board has two votes in cases of disputes and the head is appointed by the shareholders. However, disputes are rather rare. In the case of firms with between 500 and 2000 employees the weaker one-third codetermination law applies, in which case $33 \%$ of the seats of the supervisory board go to the labor representatives ${ }^{21}$. Employees are legally involved in decision-making on the supervisory board such that in contrast to what the shareholder value approach proposes, the employee's interests should also be taken into account. The fact that employees get control rights raises the question to what extent their interests differ from or are in line with those of the shareholders' ones ${ }^{22}$. The literature discusses this question quite heterogeneously.

of 812 U.S. firms it turns out that CEO compensation is more positively associated with accounting performance when firms have high compensation committee quality.

19 Codetermination encompasses three laws: In 1951 the Iron and Steel Codetermination Act enacted occupation of $50 \%$ of all seats in supervisory boards of iron and steel companies by representatives of labor. The Works Constitution Act of 1952 granted labor representatives one third of all seats of supervisory boards in all companies if a firm has 500 employees or more. In 1976 the Co-determination Act extended the $50 \%$ rule to all companies with 2000 employees or more. To secure decision-making capabilities in case of dispute the head of the supervisory board, appointed by the capital owners, has two votes. However, disputes are rare.

${ }^{20}$ Germany is the largest economy in which employees have the legal right to such participation. Denmark, Sweden, Austria, the Netherlands and Luxembourg have similar codetermination laws. Italy and the remaining West European countries (with the exception of the UK) implement work councils at the very least. French companies send non-voting employees to the board (Smith 1991)

${ }^{21}$ The employment limit is relevant to the company alone or, if it is a conglomerate or the company has subsidiaries, the total number of employees is decisive. The codetermination status of several companies deviates from the simple "individual firm employment rule" and it is unclear whether existing empirical studies have taken this into account. For quasi-parity codetermination reliable information is available from the Hans-Böckler Stiftung. Unfortunately, for one-third codetermination no such information is obtainable. 22 McPherson (1951, p. 27) already stated more than 60 years ago: "In any case, the new structure of control [...] will provide an interesting test of the often debated degree of mutuality of interest of owners, managers, and employees 
As proponents of the property rights theory, Jensen and Meckling (1976) doubt the efficiency of codetermination. They argue that if codetermination were beneficial then there would be no need for it to be mandatory. This argument supports the hypothesis that codetermination must be detrimental to shareholder value because employees' interests differ from those of the shareholders.

The literature on managerial compensation also considers labor representation as a possible cause for a weaker incentive orientation. For example, in their well-known study Jensen and Murphy (1990) find a rather weak correlation between performance and managerial remuneration. In their view this result might be caused by public and private politically orientated forces like unions, which limit the incentive orientation of contracts. The influence of such institutions may then partly be responsible for the inefficient design of executive pay.

Gorton and Schmid (2004) regard the German system of codetermination as one sort of labor participation in corporate decision making. Codetermination reduces shareholder wealth because the employee representatives might use their influence to "insure" the employees against negative shocks. This is realized by resistance against restructuring, layoffs, and wage reductions ${ }^{23}$. Gorton and Schmid (2004) then go one step further and argue that employee representatives are in favor of a low share of total compensation being performance-related. Then top management would be less orientated towards profit maximization and cost minimization.

In contrast to the property right theory, participation theory (e.g. Freeman and Lazear 1995) argues that involving employees in the decision-making process could imply a substantial information advantage and therefore have a positive impact on productivity. An important aspect of an employee's economic value is their years of experience, which is related to advanced skills and abilities of special value to the current company (Smith 1991). Thus employees invest in specific human capital which is only productive in the present employment relationship. On the one hand, labor representatives on the supervisory boards may execute the voice option in the sense of the Freeman and Medoff (1984) exit-voice theory and by this reduce quits. On the other hand, worker representatives may safeguard the increased investment in firm-specific human capital by

\footnotetext{
${ }^{23}$ However, in Germany wage negotiations take place between trade unions and employers' associations. Wages differ between firms and there might also be some influence from works councils, but the impact of codetermination in the supervisory board on wages is probably rather limited. Slower employment adjustment might be an issue, however. Gorton and Schmid (2004) also recognize this point and test several alternative hypotheses supporting overemployment but not wage increases.
} 
adequate decisions on strategic decisions including managerial incentives. Witt (2002) points out that especially with respect to dismissals and bankruptcy the long-term interests of shareholders and employees may well be similar ${ }^{24}$.

In this connection Edwards et al. (2009) argue that employees may be good monitors of managerial performance because of their close knowledge of the firm's operations. Similarly Fauver and Fuerst (2006) point out that labor representatives on supervisory boards are highly informed monitors who reduce managerial agency costs as well as private benefits of blockholder control. They stress that unlike other members of the supervisory board the representatives of the workers have detailed information on the daily operations and processes taking place at the firm. They acquire knowledge on the feasibility of projects in practice and on the problems as well as advantages associated with new technologies.

We argued earlier that the German board system might suffer from inefficiency due to structural and agency problems. Consequently, the interests of the shareholders will probably not be represented adequately on the supervisory board. The representatives of the workers on the board may well be more independent in the sense of Adams, Hermalin and Weisbach (2010) and might therefore control CEOs more carefully than the representatives of the capital owners. Perhaps surprisingly, here the representation of the employees on the supervisory board may serve as a substitute for the underrepresented or unrepresented interests of the shareholders.

Quite early directly after the implementation of the first codetermination law McPherson (1951) argues that employees and shareholders have similar interests as most members of both groups have long-run relations to the firm in question. This may not hold for managers as allegedly at least some of them have a focus on short-run optimization ${ }^{25}$. If so, the employees' representatives will try to limit short-run optimization, the pursuit of overly risky projects and excessively costly expansion policies e.g. by merger or acquisition. As a consequence, codetermination may have a positive impact on executive compensation in terms of a stronger link between compensation and performance.

\footnotetext{
${ }^{24}$ FitzRoy and Kraft $(1993,2005)$ discuss the possible effects of codetermination on employees' job security and observed productivity.

${ }^{25}$ McPherson 1951, p. 25:”It can be argued that the employees have as great interest as the stockholders in the general conduct of a corporation, since the livelihood, particular of the older long-service employees, is largely dependent upon the success of the enterprise. Also it can be said that there is approximately as much continuity in the relationship between the employees and the company as between the stockholders and the company."
} 


\section{Empirical study}

The following empirical study analyses the impact of codetermination on management compensation. We want to examine empirically whether the assumed difference in the objective function of shareholders and employees really exists. In order to do so we will analyze the link between codetermination and management compensation.

Our general research strategy is the investigation of the ratio of variable to total compensation. In contrast to fixed compensation the variable share of compensation actually depends on short-term and long-term firm performance. Thus, the share of variable compensation indicates the incentive orientation of managerial remuneration.

\subsection{Data}

Our dataset is composed of five different sources. As mentioned earlier, detailed data on executive compensation has been available for some years. Kienbaum Consulting collects data on different components of executive compensation and provided us with this information on large German corporations. Covering the years 2006 to 2011, this dataset contains, besides total average executive compensation per head, detailed information on fixed compensation and performance-based compensation. The variable part of the remuneration is differentiated into short-term and long-term incentive orientated payments.

We combine the Kienbaum dataset with the database "dafne" provided by Bureau van Dijk, which contains companies' information on economic variables, which in turn potentially explain the components of managers' compensation. This dataset contains among other items comprehensive information on companies' financial performance and employment. The information on quasi-parity codetermined companies was provided by the Hans Böckler Foundation. Furthermore we use OECD data on the labour costs per employee on industry level. Eventually, a unique unbalanced panel is assembled, consisting of 405 German stock-listed firms covering the periods 2006 to 2011 with 1713 observations overall.

Table 1 below lists definitions of the variables used and presents descriptive statistics for the whole sample. RVariable describes the ratio of variable to total executive compensation, whereas the variable part is defined as the sum of short-term variable and 
long-term variable parts. Thus, on average 38 percent of total per head compensation is variable $^{26}$. The variable LaborCostperEmploy represents the average per head labour costs (compensation of employees) on industry level measured in Euro. According to participation theory investment into firm-specific human capital increases employees’ interest in efficient management decisions and then an effect on incentive orientation of executive compensation is plausible. Specific human capital is usually reflected in wage levels

The number of executive board members is represented by EBoardMembers. We control for accounting profitability by using current and lagged information on returns on equity in percent (ROE and LagROE, respectively) as performance indicator. The size of a company is represented by the number of employees. On average we observe companies with more than 13,000 employees. The dummy DProfit assumes unit value if the balance sheet total is positive and zero otherwise. In our sample 77 percent of the companies have a positive balance sheet total. The variable intDProfitROE represents an interaction between DProfit and ROE. Unsurprisingly the mean value of returns on equity of those companies with a positive balance sheet total is, at 9.65 percent, higher than the mean value of all companies in the current period (3.85 percent). DCodet serves as a dummy variable which takes the value one if it is an equal-representation company and zero otherwise. Around one quarter of our sample is represented by parity codetermined companies.

Table 1: Descriptive Statistics for 2006-2011 (mean values and standard deviations)

\begin{tabular}{lcc}
\hline & mean & sd \\
\hline RVariable & 0.382686 & 0.227071 \\
LaborCostperEmploy & 40772.18 & 9330.883 \\
EBoardMembers & 3.080064 & 1.389584 \\
LagROE & 4.153216 & 30.07469 \\
$R O E$ & 3.848509 & 23.43952 \\
Employ & 13250.66 & 48392.53 \\
& & \\
& & \\
& \\
percent long run components(the long run components include exercised stock-based compensation as well \\
as fair values of stock-rights received at the grant date). Additionally, we test empirically on the relation \\
between one performance indicator and total compensation. Moreover, it is investigated whether the \\
(lagged value of ratio of the variable part of compensation relative to total compensation really intensifies \\
the relation between the performance measure and total compensation.
\end{tabular}




$\begin{array}{lcc}\text { DProfit } & 0.773099 & 0.418950 \\ \text { intDProfitROE } & 9.654398 & 9.75455 \\ \text { DCodet } & 0.243275 & 0.429185\end{array}$

Number of Observations 1710

Figure 1 shows the composition of executive compensation over the years for German companies without and with codetermination in terms of quasi-parity representation. Obviously, the compensation structure of companies with parity representation differs strongly from companies without parity representation. The mean value of the variable share of total compensation over the whole period is 31 percent for non-codetermined companies and 52 percent for codetermined companies. Thus, from a descriptive point of view, codetermined companies use a higher share of short-term as well as long-term performance-based compensation. These descriptive statistics give reason to hypothesize that codetermined companies determine executive compensation in a more incentivebased way than others. In the next step we check whether this presumption holds in a causal context by means of regression analysis.

\section{Figure 1: Composition of Executive Compensation}

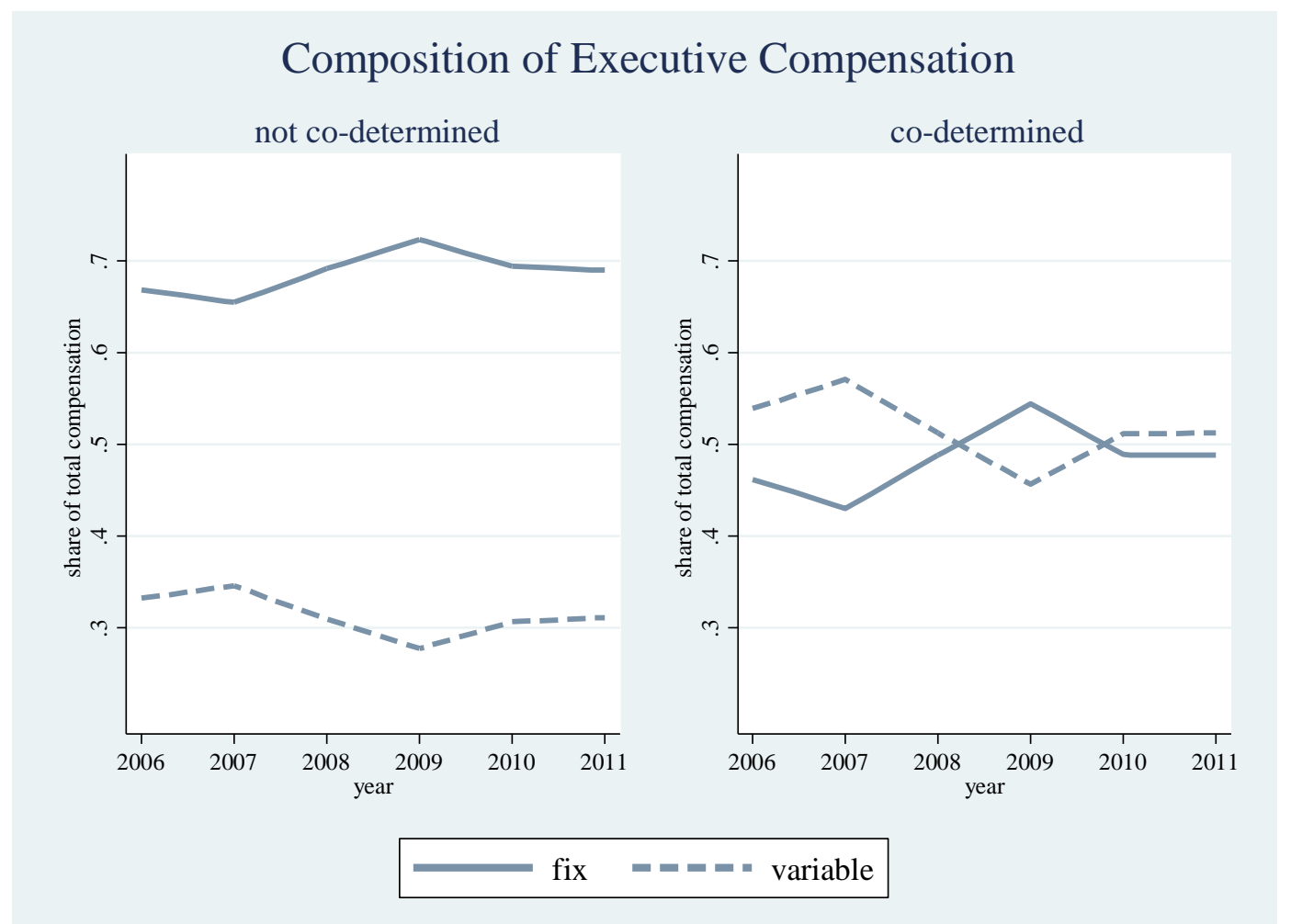




\subsection{Econometric Framework}

If there is no unobserved heterogeneity, random effects estimators provide a consistent and efficient estimator. Obviously our research context has to deal with the problem of unobservable company-specific effects on executive compensation which might cause a specification bias. As a matter of principle, former studies used either a fixed effect or a random effects approach to get rid of the bias caused by unobserved company-specific effects.

In this study the Hausman Test rejects the hypothesis of no correlation between fixed effects and the regressors. The use of a random effects model makes therefore at most a first step but a fixed effects model seems to be more appropriate. Indeed a fixed effects model allows controlling for systematic unobservable effects by eliminating the company-specific effect through use of deviations from means or first differences ${ }^{27}$. However, besides the advantage of eliminating unobserved effects, a severe disadvantage of the fixed effects estimator is the elimination of time-invariant variables. Given that we are interested in the effect of codetermination on compensation, which will be represented by a time-invariant dummy variable, the fixed effects method no longer serves as a suitable method.

Hausman and Taylor (1981) propose an estimator to deal with this problem using an instrumental variable method. The major advantage of the Hausman-Taylor estimator is that it permits estimation of the impact of time-invariant variables in a panel data setting while solving potential endogeneity problems ${ }^{28}$. Hausman and Taylor (1981) consider the following panel model:

$y_{i t}=X_{1 i t} \beta_{1}+X_{2 i t} \beta_{2}+Z_{1 i} \gamma_{1}+Z_{2 i} \gamma_{2}+\alpha_{i}+\varepsilon_{i t}$

with $\alpha_{i}$ representing the individual fixed effects and $\varepsilon_{i t}$ representing the error term. All

\footnotetext{
${ }^{27}$ Examples for such firm-specific influences include difficulties in monitoring executives efficiently, which induce a stronger incentive orientation of executive compensation. In contrast, firms which are exposed to high exogenous risk reduce the variable component of remuneration (Kraft and Niederprüm 1999). However, Peters and Wagner (2014) show that in the presence of high dismissal risk total compensation is higher.

${ }^{28}$ Endogeneity in the Hausman Taylor framework should not be confused with endogeneity in a simultaneous equation model. In the Hausman-Taylor model exogeneous variables are independent of unobservable fixed effects and possible simultaneous determinations of variables are not an issue. Therefore selection of exogeneous versus endogenous variables is based on independence of $\alpha_{i}$ and has nothing to do with e.g. relations with codetermination. The validity of our selection is explicitly tested.
} 
regressors are assumed to be uncorrelated with $\varepsilon_{i t}$. There are four groups of explanatory variables:

$X_{1}$ : time-variant variables, which are not correlated with $\alpha_{i}$

$X_{2}$ : time-variant variables, which are correlated with $\alpha_{i}$

$Z_{1}$ : time-invariant variables, which are not correlated with $\alpha_{i}$

$Z_{2}$ : time-invariant variables, which are correlated with $\alpha_{i}$

The main idea is to instrument the time-varying endogenous variables $\left(X_{2}\right)$ as well as time-invariant endogenous variables $\left(Z_{2}\right) . X_{2}$ variables are instrumented by their deviations from group means. The instrumental variables for $Z_{1}$ are the variables themselves. The critical time-invariant endogenous variables $Z_{2}$ are finally instrumented by means of the $X_{1}$ variables, as these variables are independent of the individual fixed effects. So the Hausman-Taylor approach uses the time averages of those time-varying regressors that are uncorrelated with $\alpha_{i}$ as instruments for the time-invariant regressors. Consequently this method requires that the number of time-variant exogenous variables is at least as large as the number of time-invariant endogenous variables. To test whether the set of instruments $X_{1}$ is legitimate, and thus uncorrelated with $\alpha_{i}$, one can use a Hausman test based on the difference between Hausman-Taylor and the within estimator (Baltagi (2013, chapter 7.4) Verbeek (2012, chapter 10.2.6), Wooldridge (2010, chapter 11.3)).

\section{Results}

Table 2 illustrates the results of a simple random effects estimation (1) and two HausmanTaylor estimations ((2) and (3)). The dependent variable is the ratio of variable to total compensation.

Whereas in the random effects approach all explanatory variables are assumed to be uncorrelated with the firm-specific effect $\alpha_{i}$, the Hausman-Taylor approach differentiates between endogenous and exogenous variables. Therefore we grouped the variables LaborCostperEmploy, EBoardMember, time dummies and interactions between the returns on equity and industry dummies (WZ2008 ${ }^{29}$-first stage) as $X_{1}$ variables ${ }^{30}$. As $X_{2}$

\footnotetext{
29 „Klassifikation der Wirtschaftszweige“ of Statistisches Bundesamt with „first-stage“ referring to the most aggregated hierarchical classification of economic activities (sections). Economic activities are divided into 21 sections. The WZ2008- second stage is divided into 88 divisions.

${ }^{30}$ As it was mentioned earlier the Hausman-Taylor approach refers to the $X_{1}$ variables as being independent of $\alpha_{i}$. Perhaps one might doubt the exogeneity of interactions between the returns on equity and industry dummies (especially because we assume the returns on equity themselves being endogenous). However,
} 
variables we set ROE, LagROE, the log of employment ${ }^{31}$ (InEmploy), DProfit and intDProfitROE. Time invariant industry dummies (WZ2008 two-digit) ${ }^{32}$ are assumed to be exogenous $\left(Z_{1}\right)$.

The exogeneity assumptions are not rejected using a Hausman test based on the difference between Hausman-Taylor and within estimator. Therefore, based on these test statistics for both Hausman-Taylor models the instruments chosen are legitimate.

The crucial difference between model (2) and model (3) is the assumption on the dummy variable DCodet in this Hausman-Taylor context. DCodet is assumed to be exogenous $\left(Z_{1}\right)$ in model (2) and endogenous $\left(Z_{2}\right)$ in model (3).

It turns out that in all three models and in contrast to previous studies the effect of parity employee representation has a positive effect on the variable share of executive compensation. If it is controlled for potential correlation between being codetermined and the individual firm-specific fixed effect using internal instruments, the impact increases and turns out to be significantly positive, even in the Hausman-Taylor context. Sometimes the fixed effects might have some relation to the time variant explanatory variables ${ }^{33}$ and here the impact of codetermination on the variable share of executive compensation is affected by firm specific effects as well. Ignoring this correlation may lead to biased results.

Summarizing, codetermined companies apply a significantly higher share of variable compensation than companies which are not codetermined. The econometric results are in accordance with the earlier presumptions which were based on Figure 1. In codetermined companies the variable share of executive compensation is on average 23 percentage points higher than in other companies.

Besides the positive impact of codetermination, the remaining controls provide further findings of major importance.

\footnotetext{
by using a Hausman test based on the difference between Hausman-Taylor and the within estimator we cannot reject the null hypothesis saying that the difference in the coefficients is not systematic. Therefore, the Hausman-Taylor estimation seems to be statistically adequate. Anyway, removing the interactions between returns on equity and industry dummies from the specification does not change the estimation results qualitatively.

${ }^{31}$ We use the log of Employ as a more flexible way to estimate the relation between firm size and the dependent variable.

${ }^{32}$ Time dummies and interaction between ROE and WZ2008 first-stage and WZ2008 two-digit are however omitted from Table 2.

${ }^{33}$ Hausman test between within estimation and random effects rejects the null hypothesis. Thus there is a systematic difference in coefficients between within and random effects.
} 
It turns out that average labour costs per employee on industry level have a significant positive impact on the incentive orientation of executive compensation. As outlined above employees with a high level of specific human capital might have an interest in safeguarding their investment by inducing adequate managerial decisions. Our results might well reflect the assumed positive correlation between specific human capital and wages and the connected incentives of employee (representatives) to pay executives incentive orientated. Thus the higher the employee wages, respectively the level of specific human capital, the higher the incentive orientation of executive compensation which might be even seen as a result of employee representation on the board level. Furthermore, the significant positive coefficient of InEmploy indicates that the larger the company, the higher the variable share of compensation. The impact of accounting performance indicators (ROE, LagROE) has to be considered in a more differentiated way. On average, once lagged returns on equity show no significant impact on the composition of management compensation. Therefore it seems that bad performance in the past does not influence future compensation design. However, an increase in current returns on equity by one percentage point increases the variable share of management compensation significantly by 0.3 percentage points. Thus the composition of management compensation significantly depends on accounting performance. By restricting the impact of returns on equity on companies with a positive balance sheet total (represented by intDProfitROE) the impact turns out to be significantly positive. Thus the degree of pay-performance sensitivity increases for companies with positive accounting performances in comparison to companies with negative accounting performances.

A similar interpretation holds regarding the coefficient of DProfit. In general companies in favorable economic conditions pay a 6.8 percentage point higher share of variable compensation than companies experiencing bad economic situations.

Obviously there seems to be a considerable asymmetry in punishing managers for bad firm decisions (resulting in a negative balance sheet total) and remunerating managers for good firm decisions (resulting in a positive balance sheet total). 
Table 2: Random Effects and Hausman-Taylor Estimation Results

\begin{tabular}{|c|c|c|c|c|}
\hline & $\begin{array}{c}\text { Random } \\
\text { Effects } \\
(1) \\
\text { RVariable } \\
\end{array}$ & & $\begin{array}{r}\text { Hau } \\
(2) \\
\text { RVariable }\end{array}$ & $\begin{array}{l}\text { Taylor } \\
\text { (3) } \\
\text { RVariable } \\
\end{array}$ \\
\hline LaborCostperEmploy & $\begin{array}{l}2.69 \mathrm{e}-06^{*} \\
(1.75)\end{array}$ & TVexogenous $\left(X_{1}\right):$ & $\begin{array}{c}4.12 \mathrm{e}-06^{* * *} \\
(2.42)\end{array}$ & $\begin{array}{l}\text { 3.65e-06* } \\
(1.91)\end{array}$ \\
\hline EBoardMembers & $\begin{array}{c}-0.0019 \\
(-0.32)\end{array}$ & & $\begin{array}{c}-0.0059 \\
(-0.84)\end{array}$ & $\begin{array}{l}-0.0119 \\
(-1.54)\end{array}$ \\
\hline LagROE & $\begin{array}{l}0.0001 \\
(0.59)\end{array}$ & TVendogenous $\left(\mathrm{X}_{2}\right)$ : & $\begin{array}{c}-0.0000 \\
(-0.14)\end{array}$ & $\begin{array}{l}-0.0000 \\
(-0.05)\end{array}$ \\
\hline$R O E$ & $\begin{array}{c}0.0036 \\
(1.13)\end{array}$ & & $\begin{array}{l}0.0032 * * * \\
\quad(3.59)\end{array}$ & $\begin{array}{l}0.0031^{* * *} \\
(3.50)\end{array}$ \\
\hline InEmploy & $\begin{array}{l}0.0494 * * * \\
\quad(8.12)\end{array}$ & & $\begin{array}{l}0.0562 * * * \\
\quad(4.06)\end{array}$ & $\begin{array}{l}0.0384 * * \\
(2.23)\end{array}$ \\
\hline DProfit & $\begin{array}{l}0.0590 * * * \\
(4.33)\end{array}$ & & $\begin{array}{l}0.0689 * * * \\
\quad(4.64)\end{array}$ & $\begin{array}{l}0.0685^{* * * *} \\
\quad(4.62)\end{array}$ \\
\hline intDProfitROE & $\begin{array}{l}0.0040 * * * \\
\quad(5.62)\end{array}$ & 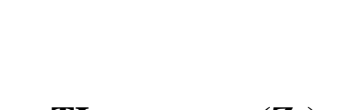 & $\begin{array}{l}0.0032 * * * \\
\quad(3.93)\end{array}$ & $\begin{array}{l}0.0031^{* * *} \\
\quad(3.88)\end{array}$ \\
\hline DCodet & $\begin{array}{l}0.0518^{* *} \\
(2.05)\end{array}$ & TIexogenous $\left(Z_{1}\right)$ : & $\begin{array}{c}0.0393 \\
(0.92)\end{array}$ & \\
\hline DCodet & & TIendogenous $\left(\mathrm{Z}_{2}\right)$ : & & $\begin{array}{l}0.2305^{* *} \\
(2.20)\end{array}$ \\
\hline _cons & $\begin{array}{c}-0.1725 \\
(-1.22)\end{array}$ & & $\begin{array}{c}-0.5821 \\
(-1.40)\end{array}$ & $\begin{array}{c}-0.7264 \\
(-1.33)\end{array}$ \\
\hline $\begin{array}{l}\chi^{2} \text { (p-value) Hausman } \\
\text { test on Hausman- } \\
\text { Taylor vs. within } \\
\text { estimation of all time- } \\
\text { variant variables }\end{array}$ & - & & $\begin{array}{c}13.06 \\
(0.7878)\end{array}$ & $\begin{array}{c}9.00 \\
(0.9402)\end{array}$ \\
\hline $\mathrm{N}$ & 1710 & & & \\
\hline
\end{tabular}

Notes: $\mathrm{t}$ statistics in parentheses; robust standard errors; ${ }^{*} \mathrm{p}<0.1,{ }^{* *} \mathrm{p}<0.05$, *** $\mathrm{p}<0.01$; TV refers to time varying; TI refers to time-invariant. Corresponding variables are deflated by cpi. Coefficients of interaction between industry dummies (WZ2008 first stage (sections)) and ROE are not reported $\left(\mathrm{X}_{1}\right)$. Time dummies are not reported $\left(\mathrm{X}_{1}\right)$. Coefficients of industry dummies (WZ2008 second stage (divisions)) are not reported $\left(Z_{1}\right)$. The reported chi value refers to a Hausman test without robust standard errors. 


\section{Robustness}

Legislation explicitly links codetermination to firm size. Similarly, composition of compensation might be related to firm size. We control for firm size by including the log of the number of employees. However, there might be a more complicated non-linear relation at work, which is not taken into account by our size variable.

In order to test whether the estimated impact of codetermination on the pay-performance sensitivity is not simply driven by size effects we divide our sub-sample of codetermined firms into large and (relatively) small firms. Therefor we separate the sub-sample of codetermined firms at the median of the number of employees $(15,030)$. Then we removed the larger codetermined firms (208 firm-years) from the whole sample and rerun our analysis with the restricted sub-sample of smaller codetermined companies. The results are shown in table 3.

Although the number of total observation decreased to 1502 our results stay robust in all models. Especially the absolute impact of codetermination only changes merely and stays as significant as in the full sample. Thus, controlling for firm size and re-running the regression with a model only including relatively small codetermined firms shows that the positive impact of codetermination on the pay-sensitivity of executive compensation is not influenced by size effects. 
Table 3: Random Effects and Hausman-Taylor Estimation Results - Robustness

\begin{tabular}{|c|c|c|c|c|}
\hline & $\begin{array}{c}\text { Random } \\
\text { Effects } \\
(1) \\
\text { RVariable }\end{array}$ & & $\begin{array}{c}\text { Haus } \\
\text { (2) } \\
\text { RVariable }\end{array}$ & $\begin{array}{l}\text {-Taylor } \\
\text { (3) } \\
\text { RVariable }\end{array}$ \\
\hline LaborCostperEmploy & $\begin{array}{l}2.73 e-06^{*} \\
(1.70)\end{array}$ & TVexogenous $\left(\mathrm{X}_{1}\right)$ : & $\begin{array}{c}4.22 \mathrm{e}-06^{* * *} \\
(2.40)\end{array}$ & $\begin{array}{l}3.89 \mathrm{e}-06^{*} \\
(1.74)\end{array}$ \\
\hline EBoardMembers & $\begin{array}{c}-0.0021 \\
(-0.29)\end{array}$ & & $\begin{array}{c}-0.0071 \\
(-0.81)\end{array}$ & $\begin{array}{c}-0.0146 \\
(-1.46)\end{array}$ \\
\hline LagROE & $\begin{array}{c}0.0001 \\
(0.43)\end{array}$ & TVendogenous $\left(\mathrm{X}_{2}\right)$ : & $\begin{array}{c}-0.0000 \\
(-0.23)\end{array}$ & $\begin{array}{c}-0.0000 \\
(-0.14)\end{array}$ \\
\hline$R O E$ & $\begin{array}{c}0.0035 \\
(1.08)\end{array}$ & & $\begin{array}{l}0.0032 * * * \\
\quad(3.85)\end{array}$ & $\begin{array}{l}0.0032 * * * \\
\quad(3.84)\end{array}$ \\
\hline InEmploy & $\begin{array}{l}0.0519 * * * \\
\quad(7.61)\end{array}$ & & $\begin{array}{l}0.0597 * * * \\
\quad(3.60)\end{array}$ & $\begin{array}{l}0.0470^{* *} \\
(2.53)\end{array}$ \\
\hline DProfit & $\begin{array}{l}0.0566 * * * \\
\quad(3.88)\end{array}$ & & $\begin{array}{l}0.0667 * * * \\
(4.14)\end{array}$ & $\begin{array}{l}0.0662 * * * \\
(4.11)\end{array}$ \\
\hline intDProfitROE & $\begin{array}{l}0.0042^{* * *} \\
\quad(5.50)\end{array}$ & 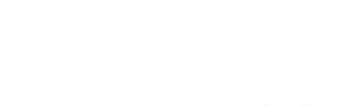 & $\begin{array}{c}0.0033^{* * * *} \\
(3.76)\end{array}$ & $\begin{array}{l}0.0033 * * * \\
\quad(3.70)\end{array}$ \\
\hline DCodet & $\begin{array}{c}0.0536^{* *} \\
(2.11)\end{array}$ & TIexogenous $\left(Z_{1}\right)$ : & $\begin{array}{l}0.0467 \\
(1.19)\end{array}$ & \\
\hline DCodet & & TIendogenous $\left(\mathrm{Z}_{2}\right)$ : & & $\begin{array}{c}0.3070 * * \\
(2.20)\end{array}$ \\
\hline _cons & $\begin{array}{l}-0.1907 \\
(-1.31)\end{array}$ & & $\begin{array}{c}-0.6183 \\
(-1.49)\end{array}$ & $\begin{array}{l}-0.9265 \\
(-1.55)\end{array}$ \\
\hline $\begin{array}{l}\chi^{2} \text { (p-value) Hausman } \\
\text { test on Hausman- } \\
\text { Taylor vs. within } \\
\text { estimation of all time- } \\
\text { variant variables }\end{array}$ & - & & $\begin{array}{c}13.75 \\
(0.7455)\end{array}$ & $\begin{array}{c}10.43 \\
(0.8844)\end{array}$ \\
\hline $\mathrm{N}$ & 1502 & & & \\
\hline
\end{tabular}

Notes: $t$ statistics in parentheses; robust standard errors; ${ }^{*} \mathrm{p}<0.1,{ }^{* *} \mathrm{p}<0.05,{ }^{* * *} \mathrm{p}<0.01$; TV refers to time varying; TI refers to time-invariant. Corresponding variables are deflated by cpi. Coefficients of interaction between industry dummies (WZ2008 first stage (sections)) and ROE are not reported ( $\left.\mathrm{X}_{1}\right)$. Time dummies are not reported $\left(\mathrm{X}_{1}\right)$. Coefficients of industry dummies (WZ2008 second stage (divisions)) are not reported $\left(Z_{1}\right)$. The reported chi value refers to a Hausman test without robust standard errors. The results refer to a restricted sample which only includes a subsample of small codetermined companies instead of all available codetermined companies. 
Up to now, our basic assumption was that a high ratio of variable payments stands for an incentive orientated contract. However, it could be possible that the variable part has only a limited or no relation to a firms’ profitability respectively a managements’ performance and serves as a "hidden" or "camouflaged" increase of fixed remuneration ${ }^{34}$. Precautionary we would like to present some evidence that justifies our basic assumption. As before we use return on equity as our variable representing profitability, as identifying long-run performance is beyond the scope of this robustness test. Return on equity is still used as an explanatory variable. Furthermore we introduce an interaction variable between return on equity and the lagged value of the ratio of variable to total compensation (intROELagRVariable). These variables and some other controls are used to explain (the log of) total compensation of executives (InTotComp). The aim of this specification is to test whether a high share of variable payments really intensifies the relation between profitability and total compensation. We use a fixed effects (model 4 in table 4) and the Arellano-Bond GMM model ${ }^{35}$ (model 5) to take account of firm specific effects and possible endogeneity which might be caused by the lagged ratio of variable to total compensation. The results are presented in table 4 . In both models the crucial interaction variable attracts positive coefficients and therefore we find that variable parts of total compensation are indeed incentive-orientated. Interestingly with regard to model 5 the ROE variable now has a negative coefficient indicating that the relation between profitability and compensation is significantly weaker in companies without any or low levels of variable components.

\footnotetext{
34 This is sometimes said about stock options.

${ }^{35}$ Regarding the Arellano-Bond framework we can reject autocorrelation of second order. The Hansen test reveals that the used instruments are valid.
} 
Table 4: Fixed Effects and Arellano-Bond Estimation Results- Robustness

\begin{tabular}{|c|c|c|}
\hline & $\begin{array}{c}\text { Fixed Effects } \\
(4) \\
\text { lnTotComp } \\
\end{array}$ & $\begin{array}{c}\text { Arellano-Bond } \\
\text { (5) } \\
\text { InTotComp } \\
\end{array}$ \\
\hline LaborCostperEmploy & $\begin{array}{c}0.00002^{*} \\
(1.95)\end{array}$ & $\begin{array}{c}0.0001^{* * *} \\
(2.44)\end{array}$ \\
\hline EBoardMembers & $\begin{array}{c}-0.0729 * * * \\
(-3.38)\end{array}$ & $\begin{array}{c}-0.1273^{* *} \\
(-2.27)\end{array}$ \\
\hline$R O E$ & $\begin{array}{c}-0.0010 \\
(-1.11)\end{array}$ & $\begin{array}{c}-0.0052^{*} \\
(-1.81)\end{array}$ \\
\hline LagRVariable & $\begin{array}{c}-0.0381 \\
(-0.47)\end{array}$ & $\begin{array}{c}0.0410 \\
(0.32)\end{array}$ \\
\hline intROELagRVariable & $\begin{array}{c}0.0057^{* *} \\
(2.44)\end{array}$ & $\begin{array}{c}0.0161^{* *} \\
(2.30)\end{array}$ \\
\hline InEmploy & $\begin{array}{c}0.3540 * * * \\
(6.07)\end{array}$ & $\begin{array}{c}-0.0104 \\
(-0.05)\end{array}$ \\
\hline DProfit & $\begin{array}{c}0.0839 * * \\
(2.41)\end{array}$ & $\begin{array}{c}0.0957 \\
(0.87)\end{array}$ \\
\hline intDProfitROE & $\begin{array}{c}0.0061^{* * *} \\
(3.18)\end{array}$ & $\begin{array}{c}0.0052 \\
(0.96)\end{array}$ \\
\hline _cons & $\begin{array}{c}2.8108 * * * \\
(4.15)\end{array}$ & \\
\hline $\begin{array}{l}\mathrm{z} \text { (p-value) Arellano-Bond test } \\
\text { for } \operatorname{AR}(2) \text { in first differences: }\end{array}$ & $(10.0)$ & $0.68(0.498)$ \\
\hline $\begin{array}{l}\chi^{2} \text { (p-value) Hansen test of } \\
\text { overid. restrictions: }\end{array}$ & - & $57.57(0.856)$ \\
\hline $\mathrm{N}$ & 1268 & 910 \\
\hline
\end{tabular}

Notes: t statistics in parentheses; robust standard errors; ${ }^{*} \mathrm{p}<0.1,{ }^{* *} \mathrm{p}<0.05,{ }^{* * *} \mathrm{p}<0.01$; Corresponding variables are deflated by cpi. Time dummies are not reported.

\section{Conclusion}

A particularity of the German corporate governance system is that management and supervision are executed by two different institutions. In the two-tier board system the executive board manages the company whereas the supervisory board supervises the enforcement of the shareholders' interests. According to codetermination law 50\% of the seats of the supervisory board must be filled by employee representatives. One explicit 
task of the supervisory board is to define the management's compensation. In order to avoid excessive risk taking and short-term optimization behavior by managers the supervisory board should ensure for an incentive-based executive compensation. This study aims at investigating the impact of labor as a stakeholder without capital shares on the incentive orientation of executive compensation.

The study investigates the effect of codetermination on the variable share of total compensation. In many cases capital shares are highly diversified and it is by no means guaranteed that the interests of the capital owners will be efficiently executed by the supervisory boards. One indication for this presumption is the low representation of capital owners on the supervisory boards. However employees' interests are in many cases well represented by works councils and these are usually members of the supervisory boards of codetermined companies. Thus, unlike supervisory board members, who represent the capital owners, employee representatives probably use their control function more efficiently.

In contrast to previous literature we argue that employees may well to a large extent have similar interests to the shareholders. In order to avoid short-term profit maximization and undue risky decisions by top management, employees quite probably support performance-based compensation schemes.

The estimates of this study show that the variable share of executive compensation in codetermined companies is on average 26 percentage points higher than in noncodetermined companies. The stronger orientation towards incentive-based compensation in codetermined companies supports our hypothesis that, similarly to shareholders, employees pursue a policy that aims at securing the long-term survival of their firm. Perhaps surprisingly, the interests of capital and labor are not necessarily opposed. In a situation with rather weak representation of shareholder interests, worker representatives may even help to realize efficient management incentives.

Our assumption that a high variable part of executive compensation is generally good for firm performance might be regarded as being too optimistic. Sub optimally designed contracts might lead to short-term orientated decisions of executives and perhaps excessive risk taking. In future work we intend to study the connection between variable compensation and profitability of firms taking account of the simultaneously determined relations between these variables. 


\section{References:}

Adams, R. B., Hermalin, B.E. amd Weisbach, M.S. (2010), "The Role of Boards of Directors in Corporate Governance: A Conceptional Framework and Survey”, Journal of Economic Literature, vol. 48, 58-107.

Addison, J. (2009), "The Economics of Codetermination: Lessons from the German Experience”, Palgrave Macmillan, New York.

Andres, C., Van den Bongard, I., Lehmann, M. (2013), "Is Busy Really Busy? Board Governance Revisited”, in: Journal of Business Finance \& Accounting, 40(9) \& (10), p. 1221-1246.

Aurich, B. (2006), Managementkontrolle nach Enron, Baden-Baden.

Baltagi B. H. (2013), Econometric Analysis of Panel Data $-5^{\text {th }}$ edition, New York.

Banning, K., Chiles T. (2007), "Tradeoffs in the Labor Union-CEO Compensation Relationship”, in: Journal of Labor Research, Vol. 28(2), p. 347-57.

Battistin, E., Graziano, C. and Parigi, B.M. (2012), "Connections and performance in bankers’ turnover”, European Economic Review, vol. 56, 470-487.

Bebchuk, L., Fried, J. (2004), "Pay Without Performance - The Unfulfilled Promise of Executive Compensation”, Harvard University Press, Cambridge.

Berle, A., Means, G. (1932), The Modern Corporation and Private Equity, New York.

Botero, J. C., Djankov, S. , La Porta, R., Lopez-de-Silanes, F., Shleifer, A. (2004), “The regulation of labor”, in: Quarterly Journal of Economics, vol. 119, p. 13391382.

Chhaochharia, V. and Grinstein, Y (2009), CEO compensation and board structure, Journal of Finance 64, 231-261.

Canyon M. J., He, L. (2004), “Compensation Committees and CEO Compensation Incentives in U.S. Entrepreneurial Firms”, in: Journal of Management Accounting Research, 16, p. 35-56.

De Cesari, A., Ozkan, N. (2015), "Executive incentives and payout policy: Empirical evidence from Europe”, in: Journal of Banking and Finance, 55, p. 70-91.

DiNardo, J., Hallock K. F., Pischke J.-S. (1997), “Unions and Managerial Pay” NBER Working Paper No. 6318.

Edwards J. S. S., Eggert W., Weichenrieder A. J. (2009), “Corporate governance and pay for performance: evidence from Germany”, in: Economics of Governance, 10(1), p. 1-26. 
Edwards, J.S.S. and Fischer, K., (1994), Banks, Finance, and Investment in Germany, Cambridge University Press: Cambridge.

Fabbri, F., Marin, D. (2015), "What Explains the Rise in Executive Pay in Germany? A Panel Data Analysis for 1977-2009”, in: Scandinavian Journal of Economics, available at: http://dx.doi.org/10.1111/sjoe.12141.

Faleye, O. (2011), "CEO Directors, Executive Incentives, and Corporate Strategic Initiatives”, in: The Journal of Financial Research, 2, p. 241-277.

Fauver, L. and Fuerst, M. E. (2006), Does Good Corporate Governance include Employee representations? Evidence from German Corporate Boards, Journal of Financial Economics, vol. 82, 673-710.

Ferris, S. P., Jagannathan, M., Pritchard, A. C. (2003), "Too Busy to Mind the Business? Monitoring by Directors with Multiple Board Appointments”, in: Journal of Finance, 58 (3), p. 1087-1111.

Fich, E. P., Shivdasani, A. (2006), “Are Busy Boards Effective Monitors?“, in Journal of Finance, 61(2), p. 689-724.

FitzRoy, F., Kraft, K. (1993), "Economic Effects of Codetermination“, in: Scandinavian Journal of Economics, vol. 95, p. 365-375.

FitzRoy, F.R. and Kraft, K. (2005), "Co-Determination, Efficiency, and Productivity“, British Journal of Industrial Relations, vol. 43, p. 233-247.

Freeman, R. B., Lazear, P. L. (1995), “An Economic Analysis of Works Councils”, in: J. Rogers, W. Streek (Edi.), Consultation, Representation, and Cooperation in Industrial Relations, Chicago und London.

Freeman, R., Medoff, J. L. (1984), “What do Unions do?”, New York.

Gorton, G. and Schmid, F. A. (2000), Universal Banking and the Performance of German Firms, Journal of Financial Economics, vol. 58, 29-80.

Gorton, G., Schmid, F. A. (2004), "Capital, Labor, and the Firm: A Study of German Codetermination”, in: Journal of European Economic Association, 2(5), p. 863-905.

Gomez, R., Tzioumis, K. (2013), "Unions and Executive Compensation", Centre for Economic Performance Discussion Paper No. 720. Available at SSRN: http://ssrn.com/abstract=1032796

Gralla, R. and Kraft, K. (2011), "Die Wirkung von Eigentümerkonzentration und Mitbestimmung auf die Produktivität”, Schmoller Jahrbuch/ Journal of Applied Social Science Studies, vol. 131, 153-167.

Hallock, K. F. (1997), "Reciprocally Interlocking Boards of Directors and Executive Compensation”, in: Journal of Financial and Quantitative Analysis, 32 (3), p. 331-343. 
Hausman J., Taylor, W. (1981), "Panel Data and Unobservable Individual Effects”, in: Econometrica, 49(6), p. 1377-1398.

Hwang B., Kim, S. (2009), "It pays to have friends”, in: Journal of Financial Economics, 93, p. 138-158.

Jensen. M. C., Meckling W. H (1979), "Rights and Production Functions: An Application to Labor-Managed Firms and Codetermination.”, in: Journal of Business, 52. p. 469-506.

Jensen, M. C., Murphy, K. J. (1990), "Performance Pay and Top Management Incentives“, in: Journal of Political Economy, 98 (2), p. 225-264.

Jirjahn, U. and Kraft, K. (2010), Teamwork and Intra-Firm Wage Dispersion Among Blue-Collar Workers, Scottish Journal of Political Economy, vol. 57 (4), 404-429.

Kraft, K. (2001), “Codetermination as a Strategic Advantage?“, in: International Journal of Industrial Organization, vol. 19, 543-566.

Kramarz, F. and Thesmar, D. (2013), Social Networks in the Boardroom, Journal of the European Economic Association, vol. 11, 780-807.

Lattemann, C. (2010), “Corporate Governance im globalisierten Informationszeitalter”, München.

Leonard, J. S. (1990), "Executive Pay and Firm Performance“, in: Industrial and Labor Relations Review, Vol. 43, Special Issue, p. 13-29.

McPherson, W. H. (1951), “Codetermination: Germany's Move Towards a New Economy”, in: Industrial and Labor Relations Review, Vol. 5 (1), p. 20-32.

Murphy, K. J. (1999), “Executive Compensation”, in: O. Ashenfelter, D. Card (eds): Handbook of Labor Economics, p.2486-2563. Amsterdam.

Murphy, K.J. (2013) "Executive Compensation: Where we are, and how we got there”, in Constantinides, G., Harris, K. and Stutz, R. (eds.) Handbook of the Economics of Finance, Vol 2, Part A, p. 211-356.

Newman H. A., Mozes, H. A, (1999), "Does the Composition of the Compensation Committee Influence CEO Compensation Practices?”, in: Financial Management, 28(3), p. 41-53.

Oehmichen, J., Schult, A., Wolff, M. (2014), "Former Executives Serving as NonExecutive Directors: Resource Channels or Ineffective Monitors”, in: Schmalenbach Business Review, 66(4), p. 438-469.

Perotti, E. C., v. Thadden, E.-L. (2006), “The Political Economy of Corporate Control and Labor Rents”, in: Journal of Political Economy, vol. 114, p. 145-175. 
Peter, F.S. and Wagner, A.F. (2014), The Executive Turnover Risk Premium, The Journal of Finance, vol. 69, 1529-1563.

Singh, P., Agarwal N. C. (2002), "Union Presence and Executive Compensation: An Exploratory Study”, in: Journal of Labor Research, Vol. 23 (4), p. 631-646.

Smith S. C. (1991), “On the economic rationale for codetermination law”, in: Journal of Economic Behavior \& Organization, 16 (3), p. 261-281.

Sun, J., Cahan, S. (2009), "The Effect of Compensation Committee Quality on the Association between CEO Cash Compensation and Accounting Performance" in: Corporate Governance: An International Review, 17 (2), p. 193-207.

[Unattributed]. Anzahl der Aktiengesellschaften und Kommanditgesellschaften auf Aktien von 1960 bis 2008. In Statista - Das Statistik-Portal. (2015, February 24), retrieved from http://de.statista.com/statistik/daten/studie/6917/umfrage/anzahl-deraktiengesellschaften-von-1960-bis-2008/

Verbeek, M. (2012), A Guide to Modern Econometrics $-4^{\text {th }}$ edition, New York.

Witt, P. (2002), "Grundprobleme der Corporate Governance und international unterschiedliche Lösungsansätze“, in: M. Nippa, K. Pezold, W. Kürsten (Hrsg.): Corporate Governance, Herausforderungen und Lösungsansätze, Heidelberg.

Wooldridge, J. M. (2010), Econometric Analysis of Cross Section and Panel Data $-2^{\text {nd }}$ edition, Cambridge, Mass, London. 